\title{
Marapu and Farming: How Tourism Shape Rural Development and Ancient Tradition of Sumba Indigenous Community - Indonesia
}

\author{
Yohanis Ngongo $^{1, *}$ and Magdalena Ngongo $^{2}$ \\ ${ }^{1}$ Assessment Institute for Agriculture Technology - East Nusa Tenggara (AIAT-ENT), Jl. Timor \\ Raya Km. 32 Naibonat - Indonesia \\ ${ }^{2}$ Senior lecture at Artha Wacana Christian University, Jl. Adisucipto - Penfui, Kupang - Indonesia
}

\begin{abstract}
Tourism National Product during 2016 - 2017. Tourism development has extended beyond "Bali" Island in Eastern Indonesia in recent years. One of the famous and well-known tourism destinations in Eastern Indonesia is located in Sumba Island. This Island settled Indigenous communities practice Marapu belief system that closed related to the traditional practicing farming that attract Tourism. The paper explores Marapu and farming traditions and how recent Tourism promotions of Sumba Island have shaped rural development and ancient traditions. Data for this study were gathered as part of the first Author study on Farming System Research in Sumba Island, East Nusa Tenggara (ENT) province in last 10 years. The study showed that Marapu tradition is still practiced for local communities, however they have been able to incorporate some crops into traditional farming system for the market demand. The paper highlight that mixed-cropping system and diversity of food commodities keeps practiced by local communities of Sumba Island in order to minimize risk in fragile ecosystem. Strategy for Tourism development in Sumba Island should strengthen the local traditions/culture particularly in farming and in the same time protecting local resources/environment.
\end{abstract}

\section{Introduction}

Marapu is local belief system by Indigenous Sumbanese communities. They believes that there is a Creator of the Universe, Holy and human being can only be communicate through ancestors and His nature of creation. The Holy Creator and His Supra-natural power cannot be fully understood and only be approached through self-purification, love, peace, respects each other, harmony life both with God and His creations. Marapu followers expressed their behave in daily life activities and rituals, for examples in related to farming Fowler, $[1,2,3]$, building sacred clan house [4] and practicing of dowry in marriage system [5].

By Sumbanese, all aspects of human life is interrelated and connected to Marapu. Marapu is also a symbol or a sign or a place to worship such as Compound Marapu, Farming Marapu, Forest Marapu, etc. Traditional farming is the most common arena where

${ }^{*}$ Corresponding author: yohanisngongo@gmail.com 
Marapu belief system practiced, starting from land preparation up to storage. Rice is considered as the most respected crops by Mагарu followers, and therefore rice normally used for many ceremonials either related to farming activities or non-farming.

All steps in farming practices, particularly for rice should be carried-out based on the unwritten Marapu procedure by Marapu Elders. Therefore production orientation, particularly rice crops is more for socio-cultural purposes rather than profit or business orientation by conducting some rituals, norms, values and believes system.

As the Creator is holy and in the highest place, Marapu followers cannot or not allowed the speak-out or pronounce His name. Only appointed Elders can whisper His name in a specific sacred ritual. The Creator' name in daily speak is only pronounced in metaphorical ways. Marapu followers believe that any material in the universe has "soul" and therefore it should be respected and manage well based on the will of Creator.

Sumba Island has been promoted as the new tourism destination beyond Bali in the last ten years. Specific pristine savannah environment and indigenous Marapu believe system that expressed in festivals/activities and ceremonies have become the main and specific "commodity" to be promoted. Indeed, Germany magazine -Focus- 2018 have chosen Sumba Island as the "most beautiful Island in the World." The reason for International Magazine - Focus- chose Sumba as the most beautiful Island in the World because its exotic savannah ecosystem, exotic beaches, its cultural heritages like unique megalithic tombs, weaving, traditional houses and Pasola riding culture [6]. Almost all cultural heritages have closely related with traditional agriculture or farming practices. In 2016, Nihiwatu Hotel and Resort in Sumba Island was rewarded as the World's Best Private Hotel 2016 [7]. These Awards help promoting tourism destinations in Sumba Island and more domestic and foreigners tourists have visiting Sumba Island.

The roles of Tourisms to improve people' income and absorb local work-force have been recognised by Local Governments in Sumba Island and therefore Central, Provincial and Districts government have contributed in developing tourism infrastructure in Sumba Island like Airports, roads, electricity and make licencing easy for accommodation development. Moreover, the spirits of Decentralization Law No. 32, 2014 have encouraging local government to look Tourism as one of the important source for Domestic/District income.

This paper argue that "commodification" of local belief system of Sumbanese Marapu through promoting Tourism development helps to conserve Marapu belief system and promoting rural development. Магари should be understood and conserved through managing and improving traditional farming practices because it contains and bridges materials and spiritual needs of Indigenous people. Improving or modernising traditional farming should be done in such ways to improve productivity and in the same time conserving the rich Marapu values as Sumbanese' cultural identity. The paper organizes as follows: after this Introduction, the next section explains Methodology briefly. The Next three sections as part of Research Findings are as follows: Socio-Cultural and Traditional Farming Ecosystem as Section Three, Tourisms Sector, Agricultural Development and Economy and Section Four and Festival Related Farming in Marapu Tradition as Section Five. The paper ended with Conclusion drawing from the previous sections.

\section{Methodology}

The paper was based on the various farming system research conducted in Sumba Island under the previous Upland Farming Development Project (UFDP) during 1993 - 2000 (Ngongo, 2005) and Assessment Institute for Agricultural Technology - East Nusa Tenggara (AIAT-ENT) in the last 10 years until recently. Purposive sampling approach employed to determine farming system research sites based on the agro-ecosystem zones 
and after discussed with LGUs in Districts level. Based on that approached, farmers settled in the research sites were also representative of some main ethnic groups or clans in Sumba such as Wewewa, Kodi and Loura in Southwestern Sumba District, Loli, Lamboya and Wanokaka in West Sumba District, and Kambera in East Sumba District.

The research sites were following the UFDP programs and or AIAT-ENT program sites in Sumba Island. Research sites in East Sumba District was more likely related to the Kambera ethnic group, while other ethnic groups distributed into western part of the Island or into three districts such as West Sumba, Middle Sumba and Southwest Sumba Districts. Description of study sites is shown at Table 1.

Table 1. Descriptions of the study sites and Agricultural Programs in Sumba Island

\begin{tabular}{|l|l|l|l|}
\hline District & Sub-District & $\begin{array}{l}\text { Main Program/ } \\
\text { Commodities }\end{array}$ & Main Ethnic group \\
\hline East Sumba & $\begin{array}{l}\text { - Lewa } \\
- \text { Pinu Pahar }\end{array}$ & $\begin{array}{l}\text { UFDP/Cashew - Mixed farming } \\
\text { system }\end{array}$ & Kambera \\
\hline $\begin{array}{l}\text { Middle } \\
\text { Sumba }\end{array}$ & - Katikutana & Food Crops/Rice and maize & Kambera,Katikutana \\
\hline West Sumba & $\begin{array}{l}\text { - Wanukaka } \\
- \text { Lamboya }\end{array}$ & Food Crops/Rice and maize & $\begin{array}{l}\text { Wanukaka, } \\
\text { Lamboya }\end{array}$ \\
\hline Southwest & $\begin{array}{l}\text { West } \\
\text { Wewewa }\end{array}$ & $\begin{array}{l}\text { Farming system/ } \\
\text { Food Crops/Rice and maize } \\
\text { Wewewa }\end{array}$ & Wewewa \\
\end{tabular}

Data related to socio-economic characteristics of farmers groups and co-operator farmers and existing farming practices were gathered in the beginning of the farming system research. Field observations were conducted during the project terms and other agricultural programs. Socio-cultural data/aspects were gathered mainly from the Elders of ethnic groups and farmers group management. Socio-cultural aspects were used and analysed descriptively to understand the rationality of traditional farming practices as a direct implementation of Marapu belied system. The authors own observation and experiences as native Sumbanese were also used to enrich the narratives.

\section{Result and Discussion}

\subsection{Socio-Cultural and Traditional Farming Ecosystem}

Following Jackson [8]' analysis on Max Weber' theory of ethnicity, the authors identified that there are 8 ethnics groups settled in Sumba Island such as Kambera, Wewewa, Kodi, Mamboro, Anakalang, Wanukaka, Loli and Lamboya. Most of the ethnic groups have their own local languages which cannot be understood by other ethnic groups, however people settled in the boundary can speak more than one local language or at least understand each local languages in nearby other ethnic group.

Socio-cultural of traditional Sumbanese is mostly guided by Marapu (religion) belief system. All rituals are carried-out to please Marapu and maintain peaceful relationships with ancestral spirits. Bad events like harvest failure or natural calamity are considered as Marapu be angry and it should be solved by doing some rituals. The Marapu's priest is responsible to carry-out the ceremony and restore the relationships with the ancestor spirits.

Based on the social strata, indigenous people of Sumba is divided into three strata such as Maromba or Maramba (nobles), Kabisu or Kabihu (Clan/priest) and Ata (common folk). Recently, the implementation of this strata system is no longer strict as before as a direct 
impact of adoption of "new faith/religion," improvement in education and economy/communication. Only in some small traditional rural people is still applied strictly this strata system, while majority of Sumbanese status is gradually changes more to the economy/wealth of household and education.

Indigenous people in the Eastern part of Sumba Island are generally more conservatives in implementing social strata values. Those in the Maramba strata have privileges in ownership or controlling natural resources particularly in terms of agricultural and grazing lands. People in Eastern part are dominated with Kambera ethnic group; while in the Western part are more complex and the social structure is less regarded and therefore distribution and access to natural resources is more fairly.

Government intervention through various agricultural programs in recent years, better accessibility and Tourist promotion of the Sumba Island have been contributed to the changing of many aspects of the farming practices and access to the natural resources. Nevertheless, small numbers of nobles class in Eastern part of the Island and in tribal groups remains as a key players in agricultural development and better access to natural resources.

Gradual changes have taken places in traditional farming practices and land use in Sumba Island. Many factors contributed for these change, however national programs in agricultural sector and tourism promotion of the Island have considered as the main primemover. The most important factor that has multiplier effects on agricultural development was the provision of land entitlement for any households to be included or get access or benefit for agricultural programs implemented in the Island (Table 2).

Table 2. Some changes in farming practices

\begin{tabular}{|c|c|c|}
\hline Land preparation & Before & Recent Practice \\
\hline Land entitlement & $\begin{array}{l}\text { - No or less } \\
\text { - Mostly under the tribal or } \\
\text { clan/kabisu control. }\end{array}$ & $\begin{array}{ll} & \text { Yes } \\
\text { - Private ownership }\end{array}$ \\
\hline Use fire & $\begin{array}{l}\text { - Common } \\
\text { - Fire break } \\
\text { - In the end of dry season. }\end{array}$ & 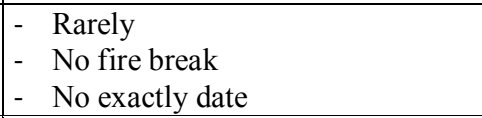 \\
\hline Tools & - Traditional & Adopt more modern innovations. \\
\hline Harvest & $\begin{array}{l}\text { - Working together } \\
\text { - Singing/admire the grains } \\
\text { - Social oriented }\end{array}$ & $\begin{array}{l}\text { Hire labor/equipment or profit } \\
\quad \text { sharing arrangement. } \\
\text { No singing } \\
\text { Profit oriented }\end{array}$ \\
\hline Product & $\begin{array}{l}\text { - More for } \text { fousehold } \\
\text { consumption/Subsistence. }\end{array}$ & - Over production for market \\
\hline
\end{tabular}

Farming practices in the upland characterises by highly diversity in terms of crops, mainly due to minimise risks or harvest failure in dominated semi-arid area and to diversify income sources. Monoculture rice farming practices in the lowland when water available enough, however rainfed lowland rice farming practices dominated in rice farming as water availability as a main constrain. In both upland and lowland farming practices, rice is still a main food crop and "admired and respected" in Marapu belief system.

\subsection{Tourism Sector, Agricultural Development and Economy}

East Nusa Tenggara (ENT) province is an archipelago province which composed of 1,192 Islands with 3 big Island such as Sumba, Timor (Western part) and Flores. Sumba Island is one of the Island which dominated with semi-arid and savannah ecosystem. Sumba Island 
attracts tourisms mainly due to its specific natural beauty ecosystem, socio-cultural of the people that practices Mагарu belief system and tomb megalithic tradition.

By its natural beauty of the Island and pristine socio-cultural, Tourists have flowering in recent years both domestic and International tourists. In 2017, there were 616,538 people tourists visited ENT province which 95,455 people were foreign tourists This figure showed that the number of foreign tourists visited ENT was more than double compare to 2013 which foreign tourists goes to Sumba Island more to take pleasure for cultural events like Pasola.

Tourism in some degrees have direct or indirectly impacts to farming practices for at least how farmer responding in providing agricultural products and all related norms/tradition in producing it. Agricultural production pattern and consumption pattern have also dictated by market demand, including from the tourism sector. Improvement tourism infrastructure have also benefited agricultural sector by promoting more efficient a demand-driven economy $[9,10]$.

Tourism in Sumba Island has just started or introduced in the end of 1980s through Tourism and Culture Ministry Regulation No. KM.4/UM.281/MPPT/1989 as Eastern part of Indonesian tourism development. However, this regulation is still focus on Bali Island, while Sumba Island received little attention. Although there were some improvement in transportation infrastructure to reach tourists destination in Sumba during 1990s, Sumba Island has just recognised in the early 2000s and then widely recognised in 2018 when German' magazine - Focus - announced that Sumba Island the most beautiful island in the world.

During 2007 - 2017, tourists visited Sumba Island increased sharply. The number of hotel/accommodation increased almost double (Table 3). The flowering of Tourism development in Sumba Island has multiplier effect on economic development and sociocultural transformation of the people living in the Island. In the same period, there has been improvement of per-capita income for people in Sumba Island from IDR 2.67 million (West Sumba) and IDR 4.13 million (East Sumba) [11] to IDR 15.88 million (West Sumba) [12] and 25.45 million [13]. District tourism sector in Sumba grows around $12 \%$ and it was the highest compare to other sector.

Table 3. Number of hotel and other accommodation, domestic and foreign tourist in four Districts of Sumba 2007 and 2017.

\begin{tabular}{|c|c|c|c|c|c|c|}
\hline \multirow[b]{2}{*}{ District } & \multicolumn{3}{|c|}{ Year 2007} & \multicolumn{3}{|c|}{ Year 2017} \\
\hline & $\begin{array}{l}\text { No. of Hotel } n \\
\text { other } \\
\text { Accommodation }\end{array}$ & $\begin{array}{l}\text { Domestic } \\
\text { tourist }\end{array}$ & $\begin{array}{l}\text { Foreign } \\
\text { tourist }\end{array}$ & $\begin{array}{l}\text { No. of Hotel } n \\
\text { other } \\
\text { Accommodation }\end{array}$ & $\begin{array}{l}\text { Domestic } \\
\text { tourist }\end{array}$ & $\begin{array}{l}\text { Foreign } \\
\text { tourist }\end{array}$ \\
\hline $\begin{array}{l}\text { East } \\
\text { Sumba }\end{array}$ & 11 & 4,131 & 288 & 16 & 14,858 & 401 \\
\hline $\begin{array}{l}\text { West } \\
\text { Sumba }\end{array}$ & 14 & 5,567 & 606 & 15 & 3,556 & 514 \\
\hline $\begin{array}{l}\text { Middle } \\
\text { Sumba }\end{array}$ & - & - & - & - & - & - \\
\hline $\begin{array}{l}\text { Southwest } \\
\text { Sumba } \\
\text { (SBD) }\end{array}$ & - & - & - & 10 & 5,164 & 378 \\
\hline $\begin{array}{l}\text { Sumba } \\
\text { Island }\end{array}$ & 25 & 9,698 & 894 & 41 & 23,578 & 1,293 \\
\hline ENT & 255 & 134,634 & 17,147 & 365 & 523,083 & 93,455 \\
\hline
\end{tabular}

Note: During 2007 Statistics Data of Middle Sumba and Southwest Sumba Districts was included in West Sumba District. 
Increasing number of hotel/accommodation and the tourist underpin economic impacts to the local economy through investment and tourist spending by assuming that mostly tourists using or consuming local products. In the area where manufacture industry has not develops yet, tourist spending is much more for agricultural products. Tourism promotion in Sumba coupled with national agricultural program has force existing farming practices to be adapted with the market demand in producing crops. Tourism development can play important part for rural development and diversification of rural economy/livelihoods [14, $15]$.

There has been fundamental transformation of agricultural farming in Sumba Island in last 30 years from mainly producing diverse food crops for subsistence to be more driven by market demand (Table 4). As Mihalic [16] stated that "Many developing countries and regions see tourism development as their chance for economic, " traditional farming and agricultural sector in Sumba are continuing transforms and adapting with the market demand.

Table 4. Some Changes in Farming Practice in Sumba Island

\begin{tabular}{|l|l|l|}
\hline Aspect & Before/Existing Practice & Recently/On-going Changes \\
\hline Crops & $\begin{array}{l}\text { - More on food crops } \\
- \text { High diversity of food crops } \\
- \text { Dominated Local varieties } \\
- \text { High social functions }\end{array}$ & $\begin{array}{l}- \text { Food and estates crops } \\
- \text { Doms diversity of food crops } \\
- \text { Low social functions }\end{array}$ \\
\hline Livestock & More for Socio-cultural purposes & $\begin{array}{l}\text { Both Socio-cultural and } \\
\text { economic purposes }\end{array}$ \\
\hline Farming Orientation & Subsistence & $\begin{array}{l}\text { Semi-commercial for food } \\
\text { crops } \\
\text { Commercial for estates crops }\end{array}$ \\
\hline $\begin{array}{l}\text { Land preparation: - Upland } \\
\text { - Lowland }\end{array}$ & $\begin{array}{l}\text { Manual, water buffalo, use fire } \\
\text { Water buffalo }\end{array}$ \\
\hline External input use & No or very low & High \\
\hline Pest and diseases & Less or rarely & More frequent \\
\hline Innovations content & Low or simply trial and error & High \\
\hline
\end{tabular}

Changes in farming orientation from subsistence to more commercial ones have changes farming landscape in Sumba Island, particularly in Western part of the Island. Expansion of annual trade crops like cashew (Anacardium occidentale) has occupied some fertile land that devoted for food crops before. It is clearly that this changes has improved cash income of upland farmers and diversifying the rural economy in one side [17-19], but in other side weakening food security of upland farmers and farmers were more dependent of external inputs [20,21].

Tourism and agricultural sectors could be both developed to improve welfare of Sumbanese and in the same time preserving/protecting Sumbanese's belief system and improving farming practices. Agricultural sector have the biggest share to Gross Regional Domestic Product (GRDP) in four districts in Sumba Island (BPS NTT, 2019) and tourism sector has been considered as important sector to absorb local agricultural products and diversifying rural people incomes.

\subsection{Festival Related Farming in Marapu Tradition}

There are some rituals and festivals related farming performed by Marapu followers in Sumba Island. Even though every tribe/clan performs specific rituals, they are all agreed that rituals conducted to gain favour and peace from Marapu and therefore they will be awarded with good harvest. 
The most important ritual/even that goes into tourism calendar in Sumba is Pasola traditional fighting. In the Pasola event, two groups of people (horse warriors) from two or more clan ride a horse/s with several javelins in their hands chase each other's while trow javelins towards opposite group. Both groups involved in Pasola should follow unwritten rules and fair play. If there is someone injury or even die during the event, there should be no revenges from opposite group. Blood from injury people is considered as the signal of soil fertility for good harvest in coming planting season.

Pasola is normally conducted earlier in two sites (tribe) such Wanukaka and Lamboya in West Sumba District and Pasola of Kodi in Southwest Sumba District. There is no exactly date for Pasola event, however a month before Pasola event should be considered as sacred month where all Marapu followers/members not allowed to do party, build a house or any activities forbidden by Marapu elders.

All aspects of Pasola is actually related to agriculture or farming which consists of four main steps such as 1). Rato or elders from the main house clan declared sacred moth after having a traditional meeting with all elders from the clan involved in the Pasola, 2). Observing the moon and natural signs (native grass/trees, wild animal's movement/behaviour) and decided the final date for Pasola. 3) Oversee the preparation before Pasola: Rato or Elders of the main Clan visiting and oversee other clan' house, do traditional fighting (pakujil) in the beach, horses rehearsal in the fighting arena, night preparation and calling/welcoming Nyale ritual and then in the early morning going to the beach to harvest Nyale which is the final step before going to the Pasola field [22].

Protection of natural resources is almost connected with maintaining traditional farming practices [23]. Pasola is way to solve the problems, tightening the relationships among Kabihu or clans, and maintaining traditional farming calendar. Pasola reflects planting calendar starts. It is also prediction of the coming crops harvest looks like and farmers are adapting it in terms of specific crops being planted and area or size of the farming.

Predicting the coming harvest have done by looking and "reading" the heart of animal/s 1 offered for Marapu (Wewewa' local term: Bara or Urrata). Marapu elders are also predicting coming harvest season by observing "the blood or injury" of the people performing the horse riding. As the "blood" is considered as the symbol of life and fertility, the blood from the people during Pasola is referring good harvest or plentiful of coming harvest season.

Preserving rituals related to Pasola have close relationship of preserving traditional farming practices. As culture is a basic motivation for tourist visitation [24] and Pasola promoted is a kind of Agritourism both intangible and tangible agricultural heritage [25], Government participate in preserving Pasola by improving infrastructures without or minimise intervention to the autonomy or independency of Marapu elders in performing all rituals related Pasola including in setting Pasola calendar. Involvements and good relationships among stakeholders in promoting Pasola have provided good environment to maintain authenticity of cultural heritage of Sumbanese [26, 27] and "strengthen the cultural identity and social integration of local communities" [28].

\section{Conclusion}

Sumba Island is one of the new tourism destinations beyond Bali in Eastern Indonesia. Sumba Island offers its natural beauty of semi-arid savannah landscapes and pristine cultural guided by Marapu's belief system including all aspects in traditional farming practices. Therefore, promoting cultural tourism base is considered promoting preservation of traditional farming practices and natural resources.

Although there were some changes in embracing new innovations in farming practices, indigenous people of Sumba keeps practicing traditional farming practice not merely to 
produce crops, but more to please Marapu which highlight "natural balance," sustainably and equity principals. The Pasola horse riding festival is a life and unfades festival of local Sumbanese in practicing Marapu's belief system related to farming.

By promoting the Sumba Island through Tourism development helps conserving the cultural traditions and in the same time promoting rural development and improvement of livelihoods of majority rural farmers. Conserving traditional farming practices can promote protection of natural resources and in the same time conserving cultural heritage.

Acknowledgments. This paper developed and inspired from the first author' involvements in Integrated Farming System Research in Sumba Island. I am indebted and acknowledged my colleagues Yeremias Bombo and Philips (Jon) Rido Dida from Waingapu Research Station of Sumba for involvement in providing "technical aspects" of farming systems in Sumba. The Authors also thank to extension workers and key-informans/local elders in Sumba for providing valuable sociocultural data and informations. Thank you also goes to my colleagues Alfonso Sitorus and Noldy R.E Kotta for editing the manuscript and references.

\section{References}

1. Fowler, C. T. (2003). The ecological implications of ancestral religion and reciprocal exchange in a sacred forest in Karendi (Sumba, Indonesia). Worldviews: Environment, Culture, Religion, 7(3), 303-329. https://doi.org/10.1163/156853503322709155

2. Fowler, C. T. (2003). The ecological implications of ancestral religion and reciprocal exchange in a sacred forest in Karendi (Sumba, Indonesia). Worldviews: Environment, Culture, Religion, 7(3), 303-329. https://doi.org/10.1163/156853503322709155

3. George, K. M., \& Hoskins, J. (1995). The Play of Time: Kodi Perspectives on Calendars, History, and Exchange. Pacific Affairs, 68(1), 143. https://doi.org/10.2307/2759803

4. Ngongo, M. (2019). Sumba wisdom in its ecology and semiotic meaning of rebuilding steps of Umbu Ndendo Clan's traditional house in Wewewa, Sumba island, Indonesia. Ecology, Environment and Conservation. EM International.

5. Kamuri, J. P., \& Toumeluk, G. M. (2021). Tinjauan Etis-Teologis Terhadap Tradisi Belis Di Pulau Sumba Berdasarkan Konsep Mahar Dalam Alkitab. Societas Dei: Jurnal Agama Dan Masyarakat, 8(1), 7-30. https://doi.org/10.33550/sd.v8i1.191.

6. A. Lewokeda, Sumba named most beautiful island by Focus. 2018 (https://en.antaranews.com/news/114784/sumba-named-most-beautiful-island-by-focusofficial).

7. Ministry of Tourism Republic of Indonesia. (Ministry of Tourism, Jakarta, 2018).

8. M. Jackson, An Analysis of Max Weber's Theory of Ethnicity. Humboldt Journal of Social Relations 10, 4 - 18 (1982).

9. G. Han, A. Akhmedov, H. Li, J. Yu, W. C. Hunter, An interpretive study on sustainability in the link between agriculture and tourism: Tourist-stakeholder satisfaction in Tiantangzhai, China. Sustainability (Switzerland) 12, (2020).

10. E. Tchouamou Njoya, A. Nikitas, GeoJournal 85, 1469-1486 (2020).

11. Nusa Tenggara Timur Dalam Angka (Nusa Tenggara Timur in Figures) 2008 (2008).

12. Sumba Timur Dalam Angka 2018 (2018).

13. Sumba Timur Dalam Angka 2018 (2018).

14. M. Št'Astná et al., Cultural tourism as a driver of rural development. Case study: Southern Moravia. Sustainability (Switzerland) 12, 1-16 (2020). 
15. R. Biddulph, Tourism and Southeast Asian rural livelihood trajectories: the case of a large work integration social enterprise in Siem Reap, Cambodia. Journal of Qualitative Research in Tourism 1, 73-92 (2020).

16. T. Mihalic, in Tourism and Development. Concepts and Issues, R. Sharpley, D. J. Telfer, Eds. (Channel View Publications., Toronto, 2014), pp. 77 - 117.

17. M. Nooripoor, M. Khosrowjerdi, H. Rastegari, Z. Sharifi, M. Bijani, The role of tourism in rural development: Evidence from Iran. GeoJournal, (2020).

18. D. Ramsey, C. D. Malcolm, The importance of location and scale in rural and small town tourism product development: The case of the Canadian Fossil Discovery Centre, Manitoba, Canada. Canadian Geographer 62, 250-265 (2018).

19. Z. Xu, B. Sun, Influential mechanism of farmers' sense of relative deprivation in the sustainable development of rural tourism. Journal of Sustainable Tourism 28, 110-128 (2020).

20. I. I. Ibeawuchi, J. C. Obiefuna, U. P. Iwuanyanwu, Low External Input Agricultural Farming System for the Increase in Productivity of Resource Poor Farmers. Journal of Biology 5, 109-117 (2015).

21. L. Myeni, M. Moeletsi, M. Thavhana, M. Randela, L. Mokoena, Barriers affecting sustainable agricultural productivity of smallholder farmers in the Eastern Free State of South Africa. . Sustainability 11, (2019).

22. Dinas Pariwisata dan Kebudayaan Kabupaten Sumba Barat. (District Government of West Sumba, 2018), vol. 2021.

23. F. Cynthia T, The ecological implications of ancestral religion and reciprocal exchange in a sacred forest in Karendi (Sumba, Indonesia). World Views Environment Culture Religion 7(3):303-329 7, 303-329 (2003).

24. H. Kajihara, S. Zhang, W. You, Q. Min, Concerns and opportunities around cultural heritage in east Asian Globally Important Agricultural Heritage Systems (GIAHS). Sustainability (Switzerland) 10, (2018).

25. N. T. Farsani, S. S. Ghotbabadi, M. Altafi, Agricultural heritage as a creative tourism attraction. Asia Pacific Journal of Tourism Research 24, 541-549 (2019).

26. J. Liang, C. S. Chan, Local cultural vicissitudes in regional tourism development: A case of Zhuhai. Tourism Management Perspectives 25, 80-92 (2018).

27. A. S. Antohin, Preserving the intangible: Orthodox christian approaches to spiritual heritage. Religions 10, (2019).

28. I. K. Surya Diarta, Between Cultural Preservation and Tourism Industry: Dialectic Relations in Cultural Heritage Tourism Management in Tanah Lot and Borobudur Indonesia. Tourism Recreation Research 45, 511-525 (2020). 